\title{
The influence of ovariectomy, simvastatin and sodium alendronate on alveolar bone in rats
}

\author{
Influência da ovariectomia, da sinvastatina e do \\ alendronato sódico no osso alveolar em ratas
}

\begin{abstract}
Ana Lia Anbinder ${ }^{(a)}$
Fernanda de Almeida Prado(b) Marcela de Almeida Prado(b) Ivan Balducci(c) Rosilene Fernandes da Rocha ${ }^{(d)}$
\end{abstract}

(a) PhD, Professor, Dentistry Department, Taubaté University (UNITAU).

(b) DDSs; (c)PhD, Professor - Department of Biosciences and Oral Diagnosis, School of Dentistry of São José dos Campos, São Paulo State University.

(d) MS, Professor, Department of Social Dentistry and Pediatric Clinics, School of Dentistry of São José dos Campos, São Paulo State University.

\begin{abstract}
Bisphosphonates are currently used in the treatment of many diseases involving increased bone resorption such as osteoporosis. Statins have been widely used for the treatment of hypercholesterolemia and recent studies have shown that these drugs are also capable of stimulating bone formation. The purpose of this study was to evaluate the influence of an estrogen deficient state and the effects of simvastatin and sodium alendronate therapies on alveolar bone in female rats. Fifty-four rats were either ovariectomized (OVX) or sham operated. A month later, the animals began to receive a daily dose of simvastatin (SIN - $25 \mathrm{mg} / \mathrm{kg}$ ), sodium alendronate (ALN - $2 \mathrm{mg} / \mathrm{kg}$ ) or water (control) orally. Thirty-five days after the beginning of the treatment, the rats were sacrificed and their left hemimandibles were removed and radiographed using digital X-ray equipment. The alveolar radiographic density under the first molar was determined with gray-level scaling and the values were submitted to analysis of variance $(\alpha=5 \%)$. Ovariectomized rats gained more weight (mean \pm standard deviation: $20.06 \pm 6.68 \%$ ) than did the sham operated animals $(12.13 \pm 5.63 \%)$. Alveolar radiographic density values, expressed as gray levels, were lowest in the OVX-water group $(183.49 \pm 6.47)$, and differed significantly from those observed for the groups receiving alendronate (sham-ALN: 193.85 \pm 3.81 ; OVXALN: $196.06 \pm 5.11)$ and from those of the sham-water group $(193.66 \pm 4.36)$. Other comparisons between groups did not show significant differences. It was concluded that the ovariectomy reduced alveolar bone density and that alendronate was efficient for the treatment of this condition.
\end{abstract}

Descriptors: Alendronate; Models, animal; Osteoporosis; Ovariectomy; Simvastatin.

Resumo: Os bisfosfonatos são empregados atualmente para o tratamento de várias doenças caracterizadas pelo aumento da reabsorção óssea, como a osteoporose. As estatinas são amplamente utilizadas para redução de níveis elevados de colesterol e estudos recentes têm revelado sua ação anabólica no osso. O objetivo deste trabalho foi avaliar a influência da deficiência estrogênica e dos tratamentos com sinvastatina ou alendronato sódico no osso alveolar em ratas. Cinqüenta e quatro ratas sofreram ovariectomia (OVX) ou cirurgia simulada ("sham"). Um mês após, os animais passaram a receber diariamente, via oral, $25 \mathrm{mg} / \mathrm{kg}$ de sinvastatina (SIN), $2 \mathrm{mg} / \mathrm{kg}$ de alendronato (ALN) ou água (controle). Trinta e cinco dias depois do início do tratamento os animais foram sacrificados, as hemimandíbulas esquerdas removidas e radiografadas em aparelho de raios X digital. Foi calculada a densidade radiográfica em tons de cinza da área de osso alveolar sob o primeiro molar mandibular e os valores foram submetidos a ANOVA, ao nível de 5\%. Ratas ovariectomizadas ganharam mais peso (média \pm desvio-padrão: $20,06 \pm 6,68 \%$ ) que as demais $(12,13 \pm 5,63 \%)$. Os valores de densidade radiográfica, em tons de cinza, foram menores nos animais do grupo OVX-água $(183,49 \pm 6,47)$, significantemente diferentes daqueles observados nos grupos que receberam alendronato ("sham"-ALN: 193,85 $\pm 3,81$; OVXALN: $196,06 \pm 5$,11) e no grupo "sham"-água $(193,66 \pm 4,36)$. Outras comparações entre grupos não revelaram diferenças estatísticas. Concluiu-se que a ovariectomia reduziu a densidade óssea alveolar e que o tratamento com alendronato sódico foi eficiente para o tratamento desta situação.

Descritores: Alendronato; Modelos animais; Osteoporose; Ovariectomia; Sinvastatina.
Received for publication on Jul 30, 2006 Sent for alterations on Oct 30, 2006 Accepted for publication on Mar 07, 2007 


\section{Introduction}

Osteoporosis is defined worldwide as a systemic skeletal disease characterized by low bone density and microarchitectural deterioration of bone tissue, which leads to increased bone fragility and risk of fracture. ${ }^{6}$ The disease should be considered as a public health problem due to its social, physical and economic impact. The majority of osteoporosis cases occur in post-menopause women, since they have an estrogen deficiency and this condition is associated to a rapid increase of bone resorption. ${ }^{6}$

Bisphosphonates are drugs that inhibit bone resorption and that have been successfully used in the systemic treatment of osteoporosis, selectively acting on bone tissue and interfering with the action of osteoclasts. ${ }^{18}$ As inhibitors of osteoclasts, bisphosphonates have been used with success in studies related to the inhibition of periodontal disease induced in animals without osteoporosis or other systemic diseases. ${ }^{16}$

Statins or 3-hydroxy-3-methyglutaryl coenzyme A (HMG-CoA) reductase inhibitors are drugs widely used over the last decade for the reduction of elevated blood cholesterol levels. Some recent studies have reported an action of these substances on bone formation through the stimulation of bone morphogenetic protein-2 (BMP-2). ${ }^{13}$ In view of these findings, it has been suggested that statins, if selectively directed at bone, may have beneficial effects on the treatment of osteoporosis and fractures. ${ }^{13}$

Thus, the objective of the present study was to evaluate the influence of the absence of ovarian hormones and the influence of simvastatin or sodium alendronate treatment on alveolar bone in rats.

\section{Material and Methods}

Fifty-four adult female Wistar rats (Rattus norvegicus) aged approximately 90 days were used. The study was conducted according to the Ethical Principles on Animal Experimentation adopted by the Brazilian College of Animal Experimentation (COBEA).

At 3 months of age, the animals were divided randomly, using a table of random numbers, with one half being submitted to bilateral ovariectomy (OVX group) and the other half, to sham surgery for the simulation of surgical stress (SHAM group).
After anesthesia with a mixture of $13 \mathrm{mg} / \mathrm{kg}$ of $2 \%$ xylazine hydrochloride (Rompun - Bayer - São Paulo, SP, Brazil) and $33 \mathrm{mg} / \mathrm{kg}$ of ketamine base (Francotar - Virbac - Roseira, SP, Brazil), and shaving of the lateral abdominal region, the skin and musculature were incised longitudinally below the last rib, and the ovary was identified and exposed. In the OVX group, hemostasis was performed by ligation of the upper part of the Fallopian tube with \#4.0 silk suture and the ovary was excised together with surrounding fat, the oviduct and a small portion of the uterus. The muscle layer was then closed with absorbable \#4.0 catgut and the skin, with \#4.0 silk suture. In the SHAM group, exposure of the ovary was followed by replacement of the organs into the abdominal cavity and suture.

Thirty days after ovariectomy or sham surgery, the rats were again randomly subdivided, according to an oral administration of $25 \mathrm{mg} / \mathrm{kg}$ of simvastatin (Sinvascor - Baldacci - São Paulo, SP, Brazil) (SIN), $2 \mathrm{mg} / \mathrm{kg}$ of sodium alendronate (TDM/AL - 013 Galena - Campinas, SP, Brazil) (ALN), or a corresponding volume of filtered water (W-control), daily, until the day of sacrifice 35 days after the beginning of treatment. The anesthetized animals were sacrificed by decapitation. The left hemimandibles were then removed and fixed in 10\% formalin.

All animals were weighed on the day of ovariectomy or sham surgery (initial weight), after 30 days (day of the beginning of treatment) and after 65 days (day of sacrifice), and the percental weight gain on days 30 and 65 was calculated. The specimens were radiographed with a digital dental X-ray apparatus (Gendex, Des Plaines, IL, USA) using the following parameters: $7 \mathrm{~mA}, 65 \mathrm{kVp}$, focus-object distance of $30 \mathrm{~cm}$, and exposure time of $0.063 \mathrm{~s}$. The hemimandible was placed upon the sensor of the apparatus in order to maintain the lingual and buccal cusps in a parallel position, thus permitting the overlapping of the radiographic images of the cusps and roots.

The radiographic density expressed as gray levels measured in the alveolar bone area under the first mandibular molar was calculated using the ImageJ 1.31p program (National Institute of Health Bethesda, MD, USA). The area analyzed was delimited between the spaces occupied by the periodontal 
ligament of the roots of the first molar and lower incisor, between the apex of the distal root of the first molar and the alveolar bone mesial to this tooth. To standardize the mesial limit of the analyzed region, an imaginary vertical line was traced connecting the space of the periodontal ligament of the lower incisor and the point of highest convexity of the mesial alveolar bone as shown in Figure 1.

Three measurements were obtained at distinct times by a single examiner who was unaware of which group the animals belonged to. The mean of the three measurements obtained for each sample was used for statistical analysis. The coefficient of variation of the repeated measurements was used to determine intra-examiner calibration. A variation of less than $5 \%$ was considered as a good degree of intra-examiner reproducibility. ${ }^{12}$ If the values of coefficient of variation were higher than $5 \%$, the measurements were repeated.

In the present study, for bone density data, the following two independent variables were analyzed:

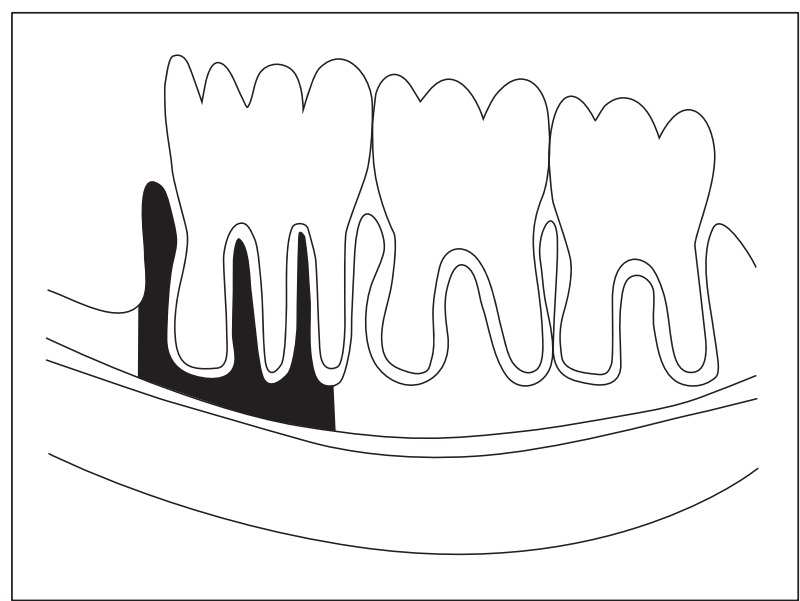

Figure 1 - Schematic drawing of the alveolar bone region where radiographic density was evaluated. ovarian hormones and drug, the first consisting of two levels, presence (SHAM group) or absence (OVX group), and the second consisting of three levels, alendronate, simvastatin or water. For analysis of changes in animal weight, besides ovarian hormones and drug, the time factor was also studied at two levels (day 30 and day 65).

The data regarding body weight and alveolar radiographic density were submitted to descriptive and inferential statistics (analysis of variance - ANOVA and Tukey multiple comparisons test; $\alpha=5 \%$ ). Statistical analysis was performed with the Statistica for Windows 5.5 (2000) (StatSoft Inc., Tulsa, OK, USA) and Statistix for Windows, version 8.0 (2003) software (Analytical Software - Tallahassee, FL, USA).

\section{Results}

For inferential statistical analysis of the data, statistical assumptions were evaluated before using the ANOVA model. The results indicated that the residuals were normally distributed. Uniformity was tested by plotting against predicted values, and none of the ANOVA assumptions was violated.

\section{Body weight}

The body weight gain data were summarized by means and standard deviation (Table 1).

Analysis of the percental body weight gain of the animals by repeated measures ANOVA showed no significant interaction effect among the three factors $\left(\mathrm{F}_{(2 ; 48)}=0.78 ; \mathrm{p}=0.4626\right)$, or between hormone and time $\left(\mathrm{F}_{(1 ; 48)}=0.41 ; \mathrm{p}=0.5258\right)$. Significant differences were observed for the main effects hormones $\left(\mathrm{F}_{(1 ; 48)}=41.14 ; \mathrm{p}<0.001\right)$ and time $\left(\mathrm{F}_{(1 ; 48)}=52.62\right.$; $\mathrm{p}<0.001$ ), but not for the main effect drug $\left(\mathrm{F}_{(2 ; 48)}=2.05 ; \mathrm{p}=0.14\right)$. For the hormones factor,

Table 1 - Mean ( \pm standard deviation) for the body weight gain data (\%).

\begin{tabular}{l|c|c|c|c|c|c}
\hline \multirow{2}{*}{$\begin{array}{c}\text { Ovarian } \\
\text { Hormones }\end{array}$} & \multicolumn{2}{|c|}{ Water } & \multicolumn{2}{c|}{ Alendronate } & \multicolumn{2}{c}{ Simvastatin } \\
\cline { 2 - 7 } & Day 30 & Day 65 & Day 30 & Day 65 & Day 30 & Day 65 \\
\hline SHAM (presence) & $9.57 \pm 5.61$ & $17.97 \pm 5.83$ & $7.88 \pm 3.32$ & $11.33 \pm 5.56$ & $10.63 \pm 3.00$ & $15.41 \pm 3.44$ \\
\hline OVX (absence) & $17.84 \pm 3.17$ & $25.35 \pm 5.03$ & $20.01 \pm 4.25$ & $24.71 \pm 5.71$ & $15.36 \pm 6.11$ & $17.09 \pm 8.71$ \\
\hline Column & $13.70 \pm 6.14$ & $21.66 \pm 6.51$ & $13.94 \pm 7.25$ & $18.02 \pm 8.79$ & $12.99 \pm 5.27$ & $16.25 \pm 6.49$ \\
\hline
\end{tabular}


Table 2 - Mean ( \pm standard deviation) for the optical density data (gray level).

\begin{tabular}{l|c|c|c|c}
\hline \multirow{2}{*}{$\begin{array}{c}\text { Ovarian } \\
\text { Hormones }\end{array}$} & \multicolumn{4}{|c}{ Drug } \\
\cline { 2 - 5 } & Water & Alendronate & Simvastatin & Row \\
\hline SHAM (presence) & $193.66 \pm 4.36$ & $193.85 \pm 3.81$ & $192.34 \pm 7.95$ & $193.28 \pm 5.50$ \\
\hline OVX (absence) & $183.49 \pm 6.47$ & $196.06 \pm 5.11$ & $189.86 \pm 8.80$ & $189.80 \pm 8.49$ \\
\hline Column & $188.58 \pm 7.49$ & $194.96 \pm 4.52$ & $191.10 \pm 8.23$ & - \\
\hline
\end{tabular}

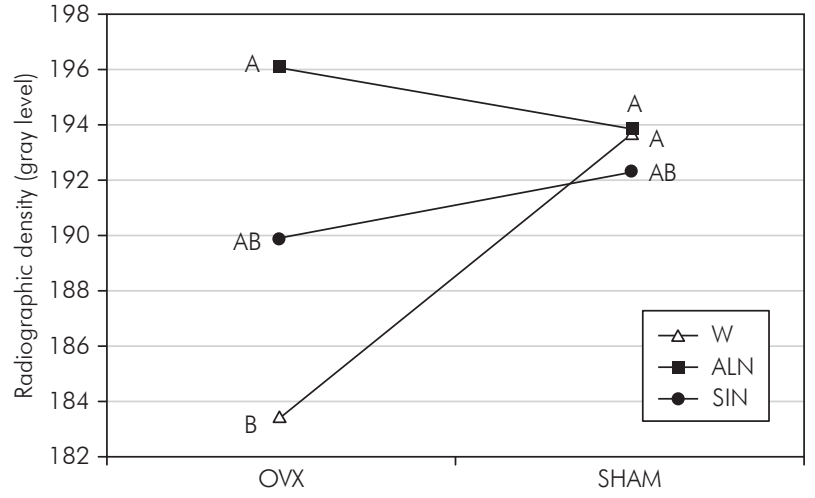

Graph 1 - Mean radiographic density (gray level) for the interaction between ovarian hormones (ovariectomizedOVX; sham operated-SHAM) and drug (simvastatin-SIN; alendronate-ALN; water-W). The same letters indicate the absence of a significant difference. The lowest value was found in group OVX-W (indicated as letter B), and it differed significantly from those observed for the groups OVX-ALN, SHAM-ALN and SHAM-W (indicated as letter A).

its absence had a positive influence on weight gain, with OVX animals showing a higher weight gain (mean \pm standard deviation, $20.06 \pm 6.68 \%$ ) than SHAM animals $(12.13 \pm 5.63 \%)$. For the time factor, the weight gain of the animals compared to the initial weight was higher on day 65 (18.64 $\pm 7.55 \%)$ than on day $30(13.54 \pm 6.16 \%)$.

\section{Alveolar density}

The coefficient of variation obtained for the three measurements of alveolar radiographic density ranged from $0.097 \%$ to $2.439 \%$. The data were submitted to descriptive statistics and means and standard deviation are shown in Table 2.

After ANOVA, significant differences were observed for the interaction effect $\left(\mathrm{F}_{(2 ; 48)}=4.36\right.$; $\mathrm{p}=0.0182)$. Considering the main effects, by plotting the means, there was a disordinal interaction for hormones $\left(\mathrm{F}_{(1 ; 48)}=4.05 ; \mathrm{p}=0.0497\right)$ and for drug $\left(\mathrm{F}_{(2 ; 48)}=4.61 ; \mathrm{p}=0.0148\right)$; thus, these effects should not be analyzed separately. The effect of the drug factor depended on the level of the hormones factor (Graph 1). The Tukey test was applied for comparison of means between the experimental conditions. Alveolar radiographic density values, expressed as gray levels, were lowest in the OVX-water group (183.49 \pm 6.47$)$, and differed significantly from those observed for the groups receiving alendronate (SHAM-ALN: $193.85 \pm 3.81$; OVX-ALN: $196.06 \pm 5.11)$ and from those of the SHAM-water group (193.66 \pm 4.36 ) (Graph 1). Other comparisons between means did not show significant differences.

\section{Discussion}

Menopausal women, deprived of the effects of estrogens and experiencing negative environmental factors such as sedentarism, show a higher tendency to gain weight. The increase of fat in these women might be related to a reduction in energy expenditure at rest and in physical activities, leading to a positive energy balance. ${ }^{14}$ Studies have shown that the removal of estrogen is related to an increase of food intake and weight gain in rodents. ${ }^{3}$ Based on the literature, in the present study the success of ovariectomy in reducing ovarian hormone levels could be demonstrated by changes in the body weight of the animals. The time factor also resulted in a significant increase of body weight, indicating the growth of the animals during the study period despite their maturity and irrespective of their hormonal situation.

Conflicting results regarding the influence of the absence of ovarian hormones on alveolar bone loss have been reported in both human and animal studies. In the present study, among animals which received water, lower bone density was observed in the ovariectomized group. Observation periods of 3 
months or longer have generally been employed in the evaluation of the effects of ovariectomy on the lower jaw, ${ }^{24}$ but Tanaka et al. ${ }^{20}$ (2002) reported a reduction in the interradicular septum of the first lower molar after 60 days. On the other hand, some authors did not observe maxillary or periodontal alterations resulting from ovariectomy. According to Teófilo et al. ${ }^{21}$ (2003), estrogen deficiency was not sufficient to promote maxillary osteoporosis in rats 11 weeks after ovariectomy. A combination of calcium and estrogen deficiency may accelerate the onset of osteoporosis signs in the maxillae of experimental animals. ${ }^{21}$

The relationship between the use of statins and improvement of bone quality reported in the literature is still controversial. Some animal studies have reported positive effects of statins on bone tissue, increasing bone formation and reducing the effects of osteoporosis, ${ }^{13}$ stimulating fracture ${ }^{19}$ and bone defect healing when applied to the site of injury, ${ }^{23}$ and increasing bone density. ${ }^{1}$ If the anabolic effect of statins is considered to be real, one possible explanation of this effect would be that small GTPases, prenylated by products of the mevalonate metabolic pathway, negatively regulate the expression of BMP-2. Inhibition of this pathway, preventing the prenylation and function of GTPases, may stimulate the expression of BMP-2, causing the proliferation and differentiation of osteoblasts and, consequently, bone formation. ${ }^{17}$

Our results are compatible with those reported by Von Stechow et al. ${ }^{22}$ (2003) and Inoue et al. ${ }^{8}$ (2003) who did not observe changes in bone tissue, after ovariectomy, or in bone healing with the administration of simvastatin. Junqueira et al. ${ }^{9}$ (2002), however, observed improvement of bone defect healing in ovariectomized rats with the use of simvastatin. The differences between the results of these studies might be attributed to variations in methodology; however, the controversy continues and further investigations are needed to clarify it.

The divergence between results is even greater in clinical and epidemiological studies conducted on humans in whom it is difficult to standardize and control variables. While some investigators reported an increase in bone density ${ }^{4}$ and a reduction in fracture risk, ${ }^{2}$ others ${ }^{7,10}$ did not find these benefits, and our results agree with theirs. The high hepatoselectivity of the drug used might be one of the reasons for its inefficacy observed in these studies. The dose tested, based on Mundy et al. ${ }^{13}$ (1999), did not improve alveolar bone tissue. Further studies are necessary to formulate doses and modes of administration that optimize the effect of statins on bone without reducing its beneficial cardiovascular effects.

In the present study, higher radiographic density was observed in animals receiving alendronate, especially those submitted to ovariectomy, suggesting that the beneficial effects of alendronate on the treatment of systemic osteoporosis may extend to alveolar bone. Bisphosphonates administered systemically have been shown to be effective in the reduction of alveolar bone loss induced by periodontal disease in animal ${ }^{16}$ and in human ${ }^{11}$ studies, showing that their complementary use in the treatment of periodontal disease seems promising. However, there are recent reports in literature of a possible association between intravenously administered bisphosphonates - prescribed for the treatment of hypercalcemia of malignancy due to multiple myeloma bone lesions or bone metastases -, or chronic oral bisphosphonate use in patients with osteoporosis or Paget's disease, and bone necrosis in the mandible or maxilla. ${ }^{5}$ Some authors have studied the successful use of topical bisphosphonates in periodontal defects in patients ${ }^{15}$ and this may be a good alternative for the use of these drugs. Most of the knowledge about the effects of bisphosphonates in the stomatognathic system comes from animal and in vitro studies. Therefore, more research is needed before these medicaments can be freely used in dental clinics.

\section{Conclusion}

Based on the methods used, we concluded that ovariectomy reduced alveolar density in rats and that sodium alendronate was effective in the treatment of this condition.

\section{Acknowledgments}

The authors wish to thank the Baldacci Laboratory (São Paulo, SP, Brazil) for granting the medicament Sinvascor. 


\section{References}

1. Anbinder AL, Balducci I, Rocha RF, Carvalho YR. Influência da sinvastatina na densidade óssea em tíbias de ratos. RPG Rev Pós-Grad. 2002;9(4):331-6.

2. Chan KA, Andrade SE, Boles M, Buist DS, Chase GA, Donahue JG et al. Inhibitors of hydroxymethylglutaryl-coenzyme A reductase and risk of fracture among older women. Lancet. 2000;355(9222):2185-8.

3. Chen Y, Heiman ML. Increased weight gain after ovariectomy is not a consequence of leptin resistance. Am J Physiol Endocrinol Metab. 2001;280:E315-22.

4. Chung YS, Lee MD, Lee SK, Kim HM, Fitzpatrick LA. HMGCoA reductase inhibitors increase BMD in type 2 diabetes mellitus patients. J Clin Endocrinol Metab. 2000;85(3):1137-42.

5. Estefania Fresco R, Ponte Fernandez R, Aguirre Urizar JM. Bisphosphonates and oral pathology II. Osteonecrosis of the jaws: review of the literature before 2005. Med Oral Patol Oral Cir Bucal. 2006;11(6):E456-61.

6. Genant HK, Cooper C, Poor R, Reid I, Ehrlich G, Kanis J et al. Interim report and recommendations of the World Health Organization task-force for osteoporosis. Osteoporos Int. 1999;10(4):259-64.

7. Hsia J, Morse M, Levin V. Effect of simvastatin on bone markers in osteopenic women: a placebo-controlled, doseranging trial [ISRCTN85429598]. BMC Musculoskelet Disord. 2002;3:7. Available from: http://www. biomedcentral. com/1471-2474/3/7.

8. Inoue TM, Anbinder AL, Balducci I, Carvalho YR. Influência da sinvastatina, administrada por via subcutânea, na reparação óssea em tíbia de rato. RPG Rev Pós-Grad. 2003;10(2):113-9.

9. Junqueira JC, Mancini MN, Carvalho Y, Anbinder AL, Balducci I, Rocha RF. Effects of simvastatin on bone regeneration in the mandibles of ovariectomized rats and on blood cholesterol level. J Oral Sci. 2002;44(3/4):117-24.

10. Lacroix AZ, Cauley JA, Pettinger M, Hsia J, Bauer DC, McGowan J et al. Statin use, clinical fracture, and bone density in postmenopausal women: results from the women's health initiative observational study. Ann Intern Med. 2003;139(2):97104.

11. Lane N, Armitage CG, Loomer P, Hsieh S, Majumdar S, Wang HY et al. Bisphosphonate therapy improves the outcome of conventional periodontal treatment: results of a 12month, randomized, placebo-controlled study. J Periodontol. 2005;76(7):1113-22.
12. Leichter JW, Pack ARC, Kardos TB. A comparison of stereological and computer-assisted histomorphometric analysis as tools for histological quantification in regenerative studies. $\mathrm{J}$ Periodontol Res. 1998;33(2):99-104.

13. Mundy G, Garret R, Harris S, Chan J, Chen D, Rossini Get al. Stimulation of bone formation in vitro and in rodents by statins. Science. 1999; 286(5446):1946-9.

14. Poehlman ET. Menopause, energy expenditure, and body composition. Acta Obstet Gynecol Scand. 2002;81(7):603-11.

15. Reddy GT, Kumar TM, Veena. Formulation and evaluation of alendronate sodium gel for the treatment of bone resorptive lesions in periodontitis. Drug Deliv. 2005;12(4):217-22.

16. Reddy MS, Weatherford TW $3^{\text {rd }}$, Smith CA, West BD, Jeffcoat MK, Jacks TM. Alendronate treatment of naturally-occurring periodontitis in beagle dogs. J Periodontol. 1995;66(3):211-7.

17. Rogers MJ. Statins: lower lipids and better bones? Nat Med. 2000;6(1):21-3.

18. Russel R, Rogers MJ, Frith JC, Luckman SP, Coxon FP, Benford HL et al. The pharmacology of bisphosphonates and new insights into their mechanisms of action. J Bone Miner Res. 1999;14(2):53-65.

19. Skoglund B, Forslund C, Aspenberg P. Simvastatin improves fracture healing in mice. J Bone Miner Res. 2002;17(11):20048.

20. Tanaka, M, Ejiri S, Toyooka E, Kohno S, Ozawa H. Effects of ovariectomy on trabecular structures of rat alveolar bone. J Periodontol Res. 2002;37(2):161-5.

21. Teófilo JM, Azevedo AC, Petenusci SO, Mazaro R, LamanoCarvalho TC. Comparison between two experimental protocols to promote osteoporosis in the maxilla and proximal tibia of female rats. Pesqui Odontol Bras. 2003;17(4):302-6.

22. Von Stechow D, Fish S, Yahalom D, Bab I, Chorev M, Muller $\mathrm{R}$ et al. Does simvastatin stimulate bone formation in vivo? BMC Musculoskelet Disord. 2003;4:8. Available from: http:// www.biomedcentral.com/1471-2474/4/8.

23. Wong RWK, Rabie ABM. Statin collagen grafts used to repair defects in the parietal bone of rabbits. Br J Oral Maxillofac Surg. 2003;41(4):244-8.

24. Yang J, Pham SM, Crabbe DL. Effects of oestrogen deficiency on rat mandibular and tibial microarchitecture. Dentomaxillofac Radiol. 2003;32(4):247-51. 